RESEARCH ARTICLE

\title{
Thickness dependence of device parameters in solid state dye sensitized solar cells
}

\author{
Jayasundera Bandara $^{1^{*}}$ and Mukundan Thelakkat ${ }^{2}$ \\ ${ }^{1}$ Institute of Fundamental Studies, Hantana Road, Kandy. \\ ${ }^{2}$ Applied Functional Polymers, Department of Macromolecular Chemistry I, University of Bayreuth, Universitat Strasse 30, 95444 Bayreuth, Germany.
}

Submitted: 08 October 2009 ; Accepted: 17 September 2010

\begin{abstract}
A solid-state dye-sensitized solar cell (SDSC) was fabricated with a very thin $(\sim 650 \mathrm{~nm})$ mesoporous $\mathrm{TiO}_{2}$ electrode and a donor-antenna (D-A) dye by using $2,2^{\prime}, 7,7^{\prime}-$ tetrakis-(N,N-di-p-methoxyphenyl-amine) 9,9'-spirobifluorene (Spiro OMeTAD) as hole conductor. A highly transparent thin electrode sensitized with D-A dye showed a short circuit current $\left(\mathrm{I}_{\mathrm{sc}}\right)$ of $4.10 \mathrm{~mA} / \mathrm{cm}^{2}$, an open circuit voltage $\left(\mathrm{V}_{\mathrm{oc}}\right)$ of $782 \mathrm{mV}$ and an efficiency of $1.79 \%$ at an illumination intensity of $100 \mathrm{~mW} / \mathrm{cm}^{2}$ ( 1 sun, $\mathrm{AM} 1.5 \mathrm{G}$ ). $\mathrm{TiCl}_{4}$ treatment of mesoporous $\mathrm{TiO}_{2}$ layer resulted in $\mathrm{I}_{\mathrm{sc}}$ of $6.18 \mathrm{~mA} / \mathrm{cm}^{2}, \mathrm{~V}_{\text {oc }}$ of $737 \mathrm{mV}$ and an efficiency of $2.12 \%$ at the same illumination intensity. This investigation demonstrates the possibility of fabrication of SDSC by way of using a very thin and transparent $\mathrm{TiO}_{2}$ electrode together with a high molar extinction coefficient D-A dye, and the effect of $\mathrm{TiO}_{2}$ layer thickness on solid-state solar cell performances is discussed.
\end{abstract}

Keywords: Donor - antenna dye, sensitization, solid-state dyesensitized solar cell, $\mathrm{TiO}_{2}$, transparent electrode.

\section{INTRODUCTION}

Dye-sensitized solar cells (DSCs) are an attractive alternative for light-to-electricity conversion applications due to their high efficiency and cost effectiveness (O'Regan \& Gratzel, 1991; Tennakone, 2001; Thelakkat, 2002). The liquid electrolyte based DSC is composed of a dye-adsorbed mesoporous $\mathrm{TiO}_{2}$ electrode, electrolyte containing $I^{-} / I_{3}^{-}$redox couple and a Pt coated counter electrode. Solid-state dye-sensitized solar cells (SDSC) are also promising due to their large potential to convert solar energy to electrical energy at low cost and their capability to solve the leakage or sealing problems that exist in liquid electrolyte dye-sensitized solar cells (Gratzel, 2003). A typical SDSC consists of several different material layers; an optically transparent compact $\mathrm{TiO}_{2}$ layer; a dye adsorbed mesoporous nanocrystalline-titanium dioxide n-type semiconductor layer; solid organic or inorganic p-type layer (hole transport layer: HTL) and a gold counter electrode.

In SDSC, photoexcited dyes inject electrons into the conduction band (CB) of the $\mathrm{TiO}_{2}$ and electron transport to the anode occurs via diffusion of electrons through the disordered $\mathrm{TiO}_{2}$ nanoparticles (van de Lagemaat et al., 2006). The diffusion electron transport mechanism plays a decisive role in the mesoporous $\mathrm{TiO}_{2}$ electrodes because of the absence of an electrical potential gradient in the films (Hagfeldt \& Grätzel, 1995; Solbrand et al., 1997). The electron transport is limited by grain boundaries of the $\mathrm{TiO}_{2}$ network and the residence time of electrons in traps. In SDSC fabricated with a mesoporous oxide layer as electron transport media and 2,2',7,7' - tetrakis - (N, N-di-p-methoxyphenyl-amine) 9,9'-spirobifluorene (spiro-OMeTAD) as hole conductor, one of the major problems is rapid charge recombination due to the weak electron transport property (Hagfeldt \& Grätzel, 1995; Solbrand et al., 1997). On one hand, the thickness of the $\mathrm{TiO}_{2}$ layer has to be the minimum possible for an efficient charge collection by anode. On the other hand, a thicker $\mathrm{TiO}_{2}$ layer is indispensable to adsorb ample dye so as to absorb greater fraction of incoming sunlight. These two opposing factors, light harvesting and charge collection, lead to an optimal thickness of the $\mathrm{TiO}_{2}$ layer in SDSCs. A thicker $\mathrm{TiO}_{2}$ layer results in incomplete pore filling of Spiro-OMeTAD in the mesoporous $\mathrm{TiO}_{2}$ layer leading to lower efficiency of the cells. i.e. A SDSC fabricated with a semitransparent $\sim 2.2 \mu \mathrm{m}$ thick $\mathrm{TiO}_{2}$ layer which is sensitized by cis$\operatorname{RuLLV}(\mathrm{SCN}) 2 \quad(\mathrm{~L}=4,4 \mathrm{~V}$-dicarboxylic acid-2,2Vbipyridine, LV=4,4V-dinonyl-2,2V-bipyridine, Z Z907)

* Corresponding author (jayasundera@yahoo.com) 
exhibits an efficiency of $\sim 4 \%$ at an illumination intensity of $100 \mathrm{~mW} / \mathrm{cm}^{2}$ with Spiro-OMeTAD as hole conductor (Schmidet-Mende et al., 2005; Schmidet-Mende \& Gratzel, 2006). The efficiency decreased to $2 \%$ when the $\mathrm{TiO}_{2}$ film thickness increased to $4 \mu \mathrm{m}$. Similar efficiency decreases have been noted for SDSC devices with D-A dye. When $\sim 1.3$ and $1.7 \mu \mathrm{m}$ semi-transparent thick $\mathrm{TiO}_{2}$ layers were sensitized with donor-antenna (D-A) dye such as Ru-TPA-NCS, 3.21 and 1.81\% efficiencies have been reported respectively at an illumination intensity of $100 \mathrm{~mW} / \mathrm{cm}^{2}$ with Spiro-OMeTAD as hole conductor (Peng et al., 2004; Snaith et al., 2008). The observed decrease in efficiency with the increase of $\mathrm{TiO}_{2}$ layer thickness was due to the combined effects of imperfect pore filling of Spiro-OMeTAD in thick mesoporous $\mathrm{TiO}_{2}$ layer and increased charge recombination. Further, the efficient pore filling of Spiro-OMeTAD has been noticed for thinner $\mathrm{TiO}_{2}$ layers with the compensation of light absorption. These findings revealed the importance of a thinner transparent $\mathrm{TiO}_{2}$ layer and a dye with a high absorption coefficient in fabrication of efficient SDSC devices. In this report, fabrication of transparent SDSC devices with thin transparent $\mathrm{TiO}_{2}$ films, D-A dye such as Ru-TPA-NCS dye having high molar extinction coefficient and Spiro-OMeTAD hole conductor is investigated.

\section{METHODS AND MATERIALS}

Titanium(IV)bis(acetoacetonato)-di(isopropanoxylate) (TAA) was purchased from Sigma-Aldrich, USA. Glass substrates (Tec 8,3mm) covered with fluorine-doped tin oxide (FTO) layer having sheet resistances of $8 \Omega$ per square $(\Omega / \square)$ were purchased from Hartford Glass Co. Inc., Indiana, USA. The $\mathrm{TiO}_{2}$ blocking layer (bl$\mathrm{TiO}_{2}$ ) was prepared by spray pyrolysis deposition (SPD) technique (Peng et al., 2004). The $\mathrm{TiO}_{2}$ precursor TAA (titanium acetylacetonate), diluted with ethanol to a concentration of $0.2 \mathrm{M}$, was used as the spraying solution and pyrolysis was carried out at $400^{\circ} \mathrm{C}$. After the required number of spraying cycles under optimized conditions, the substrates were annealed at $400{ }^{\circ} \mathrm{C}$ for another hour before cooling to room temperature. The substrates were kept in an inert atmosphere for further layer preparation. The nanocrystalline $\mathrm{TiO}_{2}$ (Dyesol - $\mathrm{TiO}_{2}$ Paste DSL 18NR-T) and terpinol mixture was deposited on the compact $\mathrm{TiO}_{2}$ layer by screen-printing. The screen-printed $\mathrm{TiO}_{2}$ was subsequently sintered by stepwise temperature programming (Karthikeyan et al., 2008). The thickness of the $\mathrm{TiO}_{2}$ layer was varied by using different $\mathrm{TiO}_{2}$ and terpinol weight ratios.

The $\mathrm{TiO}_{2}$ layer was coated with dye by leaving them overnight in a $0.5 \mathrm{mM}$ solution of Ru-TPA-NCS dye in Dimethylformamide (DMF). The procedure for the synthesis of the D-A dye has been detailed elsewhere (Karthikeyan et al., 2008). After the physisorbed dye molecules were rinsed away by dipping the samples in DMF, the samples were subsequently dried in vacuum at $45{ }^{\circ} \mathrm{C}$ for at least $1 \mathrm{~h}$. The hole-transport layer (HTL) was deposited on dye/ $\mathrm{TiO}_{2}$ layer by spin-coating. HTL solution comprises of spiro-OMeTAD $(0.16 \mathrm{M})$, and tert-butylpyridine $(0.16 \mathrm{mM})$ dissolved in water-free chlorobenzene. $\quad N$-lithiofluoromethane sulfonamide (Li-salt solution, $30 \mathrm{mM}$ ) in cyclohexanone was added as the additive. For each substrate, $70 \mu \mathrm{L}$ of the hole conductor solution was used for spin-coating. To finish, the $\mathrm{Au}$ electrode was deposited by electron beam deposition in a vacuum chamber of BA 510 type from Balzers (Liechtenstein) and the active surface was $0.12 \mathrm{~cm}^{2}$.

The photovoltaic current-voltage measurements have been carried out by a Keithley 6517 source-measure unit under AM 1.5 G conditions (xenon arc lamp, Air Mass Filters from Oriel). The intensity of light was calibrated with a standard Si-reference cell from the Fraunhofer Institut für Solarenergie (ISE), Freiburg, Germany as $100 \mathrm{~mW} / \mathrm{cm}^{2}$. All efficiency values reported in this work were not corrected with the spectral mismatch factor. The incident photon-to-photocurrent efficiency (IPCE) values were measured using a lock-in amplifier (SR830, Stanford Research Systems) with a current pre-amplifier (SR570, Stanford Research Systems) under shortcircuit conditions after illuminating the devices with monochromatic light from a xenon lamp passing through a monochromator (Spectra-model). UV-Vis spectra were recorded with a Perkin Elmer Lambda 900 spectrometer and the surface and cross-sectional features of $\mathrm{TiO}_{2}$ layers were examined using LEO 1530 Gemini field emission scanning electron microscope (FE-SEM). $\mathrm{TiO}_{2}$ films and powders were subjected to Brunauer-Emmet-Teller (BET) experiments by $\mathrm{N}_{2}$ gas adsorption performed using Micromeritics ASAP 2010 (Accelerated Surface Area and Porosimetry System), USA. Surface areas were obtained from BET examination for both $\mathrm{TiO}_{2}$ film and powders. X-ray diffraction patterns of the $\mathrm{TiO}_{2}$ powder and sintered films were examined using Philips X-Pert Multi Purpose X-ray Diffractometer, PW 3040 model with $\mathrm{Cu}$ Ka radiation.

\section{RESULTS AND DISCUSSION}

The BET measurement of the surface area of the Dyesol- $\mathrm{TiO}_{2}$ powder which was sintered at $500 \mu \mathrm{C}$ was $77.6 \mathrm{~m}^{2} / \mathrm{g}$. The BET surface area of the sintered $\mathrm{TiO}_{2}$ film on FTO glass was not measured, but it was expected to be lower than that of the powdered sample. Figure 1 shows 


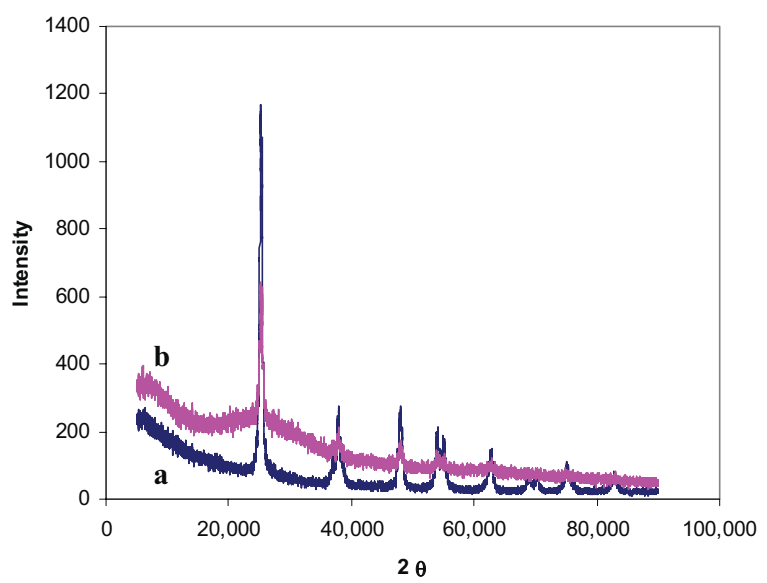

Figure 1: X-ray diffraction patterns of nanocrystalline $\mathrm{TiO}_{2}$ sintered at $450^{\circ} \mathrm{C}$ (a) Dyesol $\mathrm{TiO}_{2}$ powder and (b) Dyesol- $-\mathrm{TiO}_{2}$ film on FTO - (sample B)
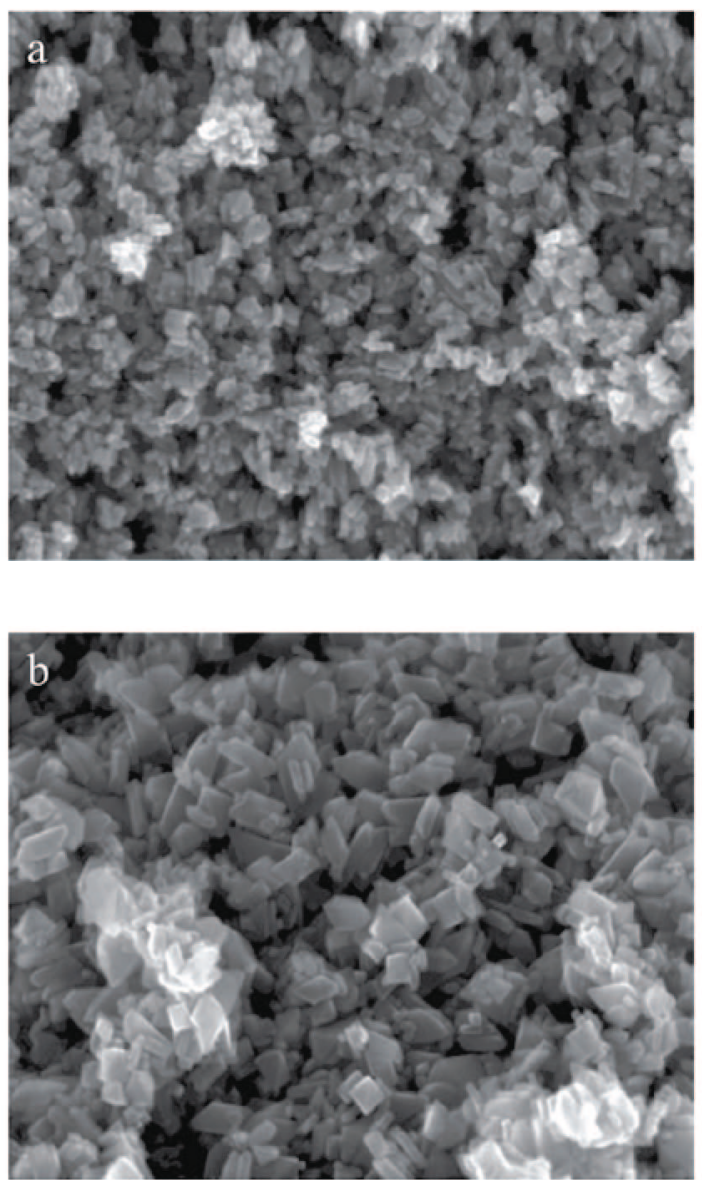

Figure 2: SEM images of (a) Dyesol- $\mathrm{TiO}_{2}$ film - (sample B), film thickness $0.65 \mu \mathrm{M}$ and (b) $\mathrm{ECN}^{-\mathrm{TiO}_{2}}$ film, film thickness $0.65 \mu \mathrm{M}$ after sintering at $450{ }^{\circ} \mathrm{C}$ the X-ray diffication (XRD) patterns of sintered Dyesol$\mathrm{TiO}_{2}$ powder and Dyesol-TiO ${ }_{2}$ film on FTO conducting glass. It is evident from the figure that the crystals of both $\mathrm{TiO}_{2}$ powder and $\mathrm{TiO}_{2}$ film have pure anatase (101) phase. Taking into account the fast electron transport and high surface area, anatase $\mathrm{TiO}_{2}$ is the preferred phase for efficient functioning of SDSC (Karthikeyan et al., 2007 $\mathrm{a}, \mathrm{b}$ ). To gain better and clear understanding of $\mathrm{TiO}_{2}$ crystal size, shape and film morphology of the sintered $\mathrm{TiO}_{2}$ films, which in turn govern the performance in SDSC, Stereo Election Microscope (SEM) examination was carried out for different film thicknesses which were prepared by changing the $\mathrm{TiO}_{2}$ paste/Terpeniol ratio (0.1: 1, 0.2:1, 0.3:1, 0.4:1, 0.5:1, 0.6:1, 0.7:1, 1:1, 1.5:1 and $2: 1 \mathrm{wt} / \mathrm{wt}$ ). All those $\mathrm{TiO}_{2}$ films prepared with different dilutions are highly transparent. Figure 2a shows the SEM image of transparent 0.2:1 diluted Dyesol- $\mathrm{TiO}_{2}$ thin film. For comparison purposes, the SEM image of semi-transparent $\mathrm{ECN}^{-\mathrm{TiO}_{2}}$ thin film is shown in Figure 2b. It is interesting to note that the nanoparticles in both Dyesol- $\mathrm{TiO}_{2}$ and $\mathrm{ECN}-\mathrm{TiO}_{2}$ films have similar shapes and they are well connected with an optimum pore size. Such a well-connected nanoparticle network is desirable for efficient functioning of SDSC because it will improve the electron percolation of the

Table 1: Variation of film thicknesses of $\mathrm{TiO}_{2}$ films with the dilution of Terpinol. Film thicknesses were measured with the use of cross-sectional images of different films.

\begin{tabular}{ccc}
\hline Sample & $\begin{array}{c}\mathrm{TiO}_{2}: \text { Terpinol } \\
(\mathrm{wt} / \mathrm{wt})\end{array}$ & $\begin{array}{c}\mathrm{TiO}_{2} \text { film } \\
\text { thickness }(\mu \mathrm{m})\end{array}$ \\
\hline $\mathrm{A}$ & $0.1: 1$ & 0.300 \\
$\mathrm{~B}$ & $0.2: 1$ & 0.650 \\
$\mathrm{C}$ & $0.3: 1$ & 0.850 \\
$\mathrm{D}$ & $0.4: 1$ & 1.3 \\
$\mathrm{E}$ & $0.6: 1$ & 2.4 \\
$\mathrm{~F}$ & $1: 1$ & 3.1 \\
$\mathrm{G}$ & $2: 1$ & 5.8 \\
\hline
\end{tabular}

Table 2: Variations of solar cell performances with the variation of $\mathrm{TiO}_{2}$ film thicknesess

\begin{tabular}{ccccc}
\hline $\begin{array}{c}\mathrm{TiO}_{2} \text { film } \\
\text { thickness }(\mu \mathrm{m})\end{array}$ & $\mathrm{I}_{\mathrm{sc}}\left(\mathrm{mA} / \mathrm{cm}^{2}\right)$ & $\mathrm{V}_{\mathrm{oc}}(\mathrm{mV})$ & $\mathrm{FF}(\%)$ & Efficiency (\%) \\
\hline 0.30 & 3.60 & 727 & 40.3 & 1.05 \\
0.65 & 4.07 & 782 & 54.0 & 1.72 \\
0.85 & 6.72 & 687 & 38.8 & 1.70 \\
1.3 & 6.06 & 672 & 39.1 & 1.59 \\
2.4 & 3.93 & 672 & 41.4 & 1.12 \\
3.1 & 2.26 & 687 & 30.1 & 0.47 \\
5.8 & 1.99 & 682 & 29.8 & 0.41 \\
\hline
\end{tabular}


system. However, the crystal size of Dyesol- $\mathrm{TiO}_{2}$ is 5-10 nm, whereas $\mathrm{ECN}-\mathrm{TiO}_{2}$ has a large size distribution $(10-80 \mathrm{~nm})$. The thickness of the Dyesol- $\mathrm{TiO}_{2}$ film as a function of dilution of the $\mathrm{TiO}_{2}$ paste was analyzed by cross-section SEM images of the films. Figures $3 a$ and $3 \mathrm{~b}$ show the cross-section SEM images of 0.2:1, 0.6:1 and 1.4:1 (wt/wt) diluted Dyesol- $\mathrm{TiO}_{2}$ films, and the calculated film thicknesses as a function of dilution is given in Table 1. As shown in Table 1, the thickness of the $\mathrm{TiO}_{2}$ film varied from $\sim 300 \mathrm{~nm}$ to $\sim 3.5 \mu \mathrm{m}$ for $0.1: 1$ to $1.4: 1(\mathrm{wt} / \mathrm{wt})$ diluted $\mathrm{TiO}_{2}$ pastes respectively. When the cross-sectional SEM images of the Dyesol- $\mathrm{TiO}_{2}$ film (Figure 4) were examined at a higher magnification, well dispersed uniform sized nanoparticles that were well connected without forming agglomerates were visible. These well connected nanoparticles facilitate efficient charge transport and collection at the device electrodes.

The molecular structure of the Ru-TPA-NCS D-A dye used in this study is shown in Figure 5a. The extended $\pi$-electron delocalization in the bpy ligand enables the D-A dye molecules to have very high molar extinction coefficients $\sim 58,000 \mathrm{lmol}^{-1} \mathrm{~cm}^{-1}$ at $440 \mathrm{~nm}$ and 25, 000 $1 \mathrm{~mol}^{-1} \mathrm{~cm}^{-1}$ at $540 \mathrm{~nm}$ (Karthikeyan et al., 2008). The extended separation of electron and holes realized in Ru-TPA-NCS has been shown to retard the recombination process at the $\mathrm{TiO}_{2}$-dye interface and at the $\mathrm{TiO}_{2}$-hole conductor interface in solid state solar cells (Handa et al., 2007; Boschloo et al., 2008). This is of particular interest in SDSCs employing organic hole - transporting materials (HTMs) as it suffers from fast interfacial charge recombination losses relative to liquid electrolyte based devices. Figure $5 \mathrm{~b}$ shows the absorption spectra of Ru-TPA-NCS adsorbed Dyesol- $\mathrm{TiO}_{2}$ films as a function of film thickness. For this study, the thickness of $\mathrm{TiO}_{2}$
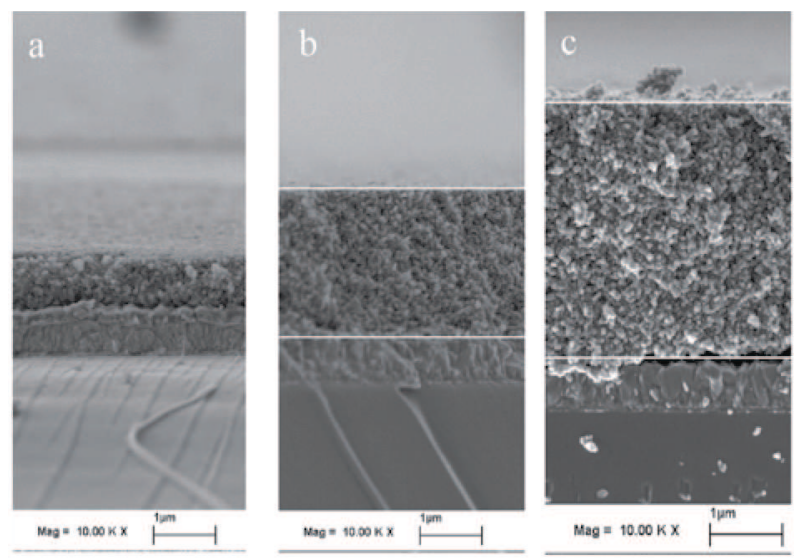

Figure 3: Cross-section view of the Dyesol- $\mathrm{TiO}_{2}$ film prepared with different dilutions (a) 0.2:1 (sample $\mathrm{B}-\mathrm{TiO}_{2}$ :Terpinol wt/wt), (b) $0.6: 1$ (sample $\mathrm{E}-\mathrm{TiO}_{2}:$ Terpinol wt/wt) and (c) $1.4: 1\left(\right.$ sample $\mathrm{F}-\mathrm{TiO}_{2}:$ Terpinol wt/wt) film was changed from $300 \mathrm{~nm}$ to $2.4 \mu \mathrm{m}$. It is clear that thicker samples show better adsorption of the dye compared to thinner ones. It is also evident from Figure $5 b$ that the dye uptake increases linearly with the increase of the $\mathrm{TiO}_{2}$ film thickness. The quantification amount of adsorbed dye on Dyesol- $\mathrm{TiO}_{2}$ film cannot be performed accurately owing to difficulty of complete desorbing of the adsorbed Ru-TPA-NCS dye on Dyesol- $\mathrm{TiO}_{2}$ films.

Since these donor-antenna dyes have extremely high molar extinction coefficients, it is possible to use thinner $\mathrm{TiO}_{2}$ layers having comparable optical density to that of a thicker $\mathrm{TiO}_{2}$ film in SDSC application. In order to check this principle, the influence of $\mathrm{TiO}_{2}$ thickness on SDSC performance was studied using D-A dye Ru-TPA-NCS. $\mathrm{I}-\mathrm{V}$ characteristics of solar cells fabricated with different $\mathrm{TiO}_{2}$ film thicknesses (300 nm - $2.4 \mu \mathrm{m}$ thick $\mathrm{TiO}_{2}$ films) sensitized with Ru-TPA-NCS dye are shown in Figure $6 \mathrm{a}$ and Table 2. Figure $6 \mathrm{~b}$ shows the plot of variation of short circuit photocurrent density $\left(\mathrm{I}_{\mathrm{sc}}\right)$, open circuit potential $\left(\mathrm{V}_{\mathrm{oc}}\right)$ and efficiency against the film thickness. As shown in Figure 6, the thinnest $\mathrm{TiO}_{2}$ film $(\sim 300 \mathrm{~nm})$ showed an $\mathrm{I}_{\mathrm{sc}}$ of $3.60 \mathrm{mAcm}^{-2}$, a $\mathrm{V}_{\mathrm{oc}}$ of $727 \mathrm{mV}$ and a fill-factor (FF) of 0.40 resulting in an overall conversion efficiency of $\sim 1.05 \%$. Increase in $\mathrm{TiO}_{2}$ film thickness to $\sim 650 \mathrm{~nm}$ resulted in increase in $\mathrm{I}_{\mathrm{sc}}\left(4.2 \mathrm{mAcm}^{-2}\right), \mathrm{V}_{\mathrm{oc}}(782$ $\mathrm{mV})$ and $\mathrm{FF}(0.45 \%)$. As given in Table 2, the optimum $\mathrm{I}_{\mathrm{sc}}\left(6.72 \mathrm{mAcm}^{-2}\right)$ and efficiency $(1.72 \%)$ were noticed when the $\mathrm{TiO}_{2}$ film thickness was in between $650-850$ $\mathrm{nm}$ and further increase in $\mathrm{TiO}_{2}$ film thickness resulted in decrease in $\mathrm{I}_{\mathrm{sc}}, \mathrm{V}_{\mathrm{oc}}$ and FF. To investigate the variation of solar cell performance with the variation of film thickness of $\mathrm{TiO}_{2}$, the shunt and series resistances of $\mathrm{TiO}_{2}$ films were studied as a function of $\mathrm{TiO}_{2}$ film thicknesses. The dark current-voltage (dark IV) results for different

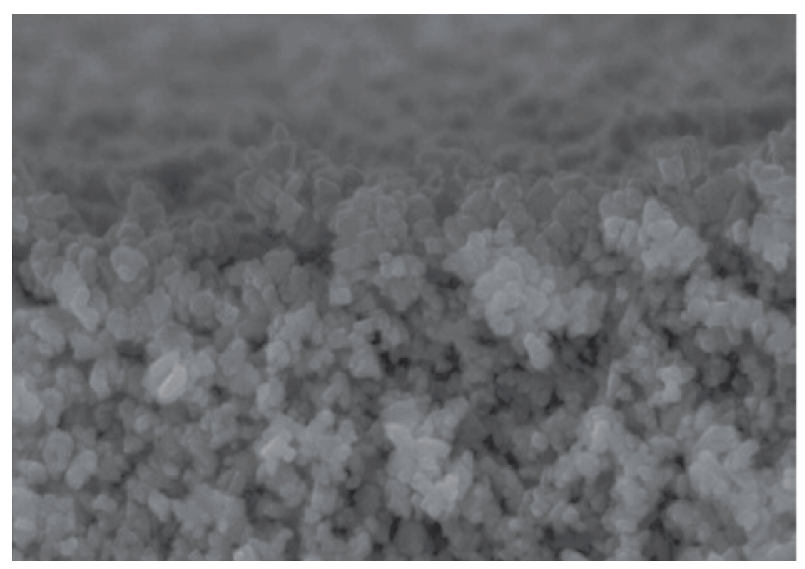

Figure 4: Magnified SEM cross-sectional image of the Dyesol- $\mathrm{TiO}_{2}$ film 0.2:1 (sample B - $\mathrm{TiO}_{2}$ : Terpinol wt/wt) 

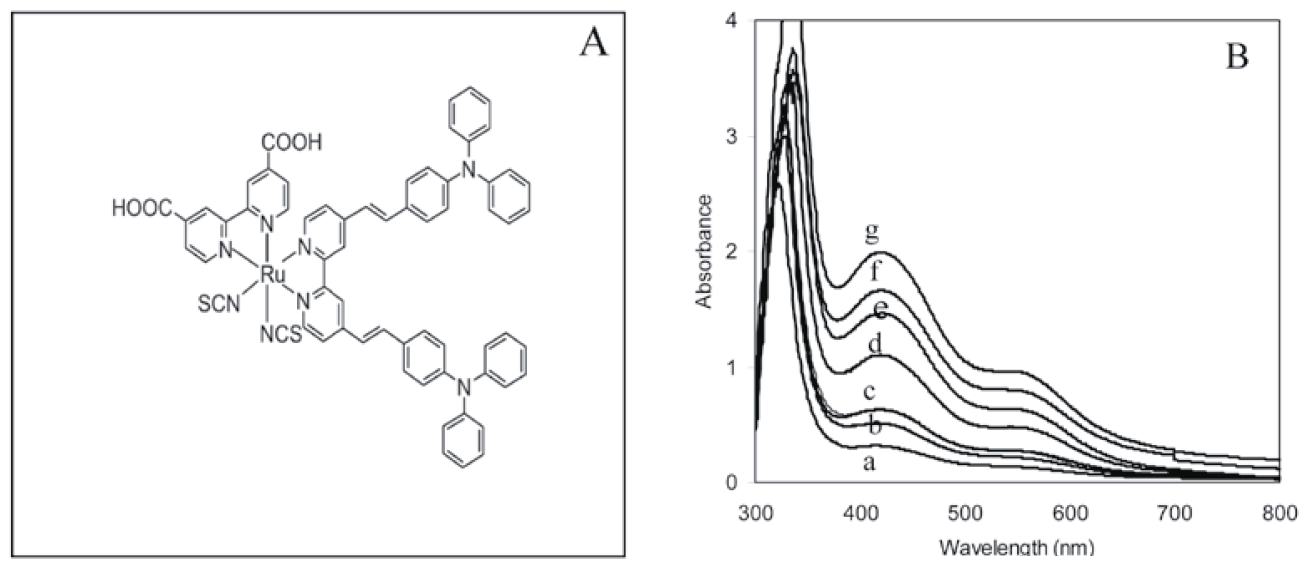

Figure 5: (A) Molecular structure of the Ru-TPA-NCS donor antenna dye, (B) UV-Vis absorption spectra of Ru-TPA-NCS adsorbed Dyesol- $\mathrm{TiO}_{2}$ film as a function of $\mathrm{TiO}_{2}$ film thickness (a) $350 \mathrm{~nm}$, (b) $650 \mathrm{~nm}$, (c) $850 \mathrm{~nm}$, (d) $1.3 \mu \mathrm{m}$, (e) $2.4 \mu \mathrm{m}$, (f) $3.1 \mu \mathrm{m}$ and (g) $5.8 \mu \mathrm{m}$

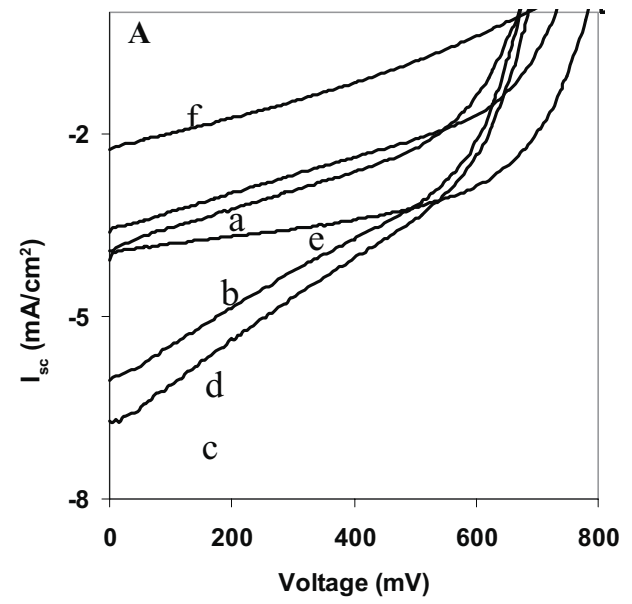

Figure 6(A): Influence of $\mathrm{TiO}_{2}$ layer thickness on currentvoltage characteristics of SDSC prepared with D-A dye, Spiro-OMeTAD with the variation of $\mathrm{TiO}_{2}$ layer thickness (a) $350 \mathrm{~nm}$, (b) $650 \mathrm{~nm}$, (c) $850 \mathrm{~nm}$, (d) $1.3 \mu \mathrm{m}$, (e) $2.4 \mu \mathrm{m}$, (f) $3.1 \mu \mathrm{m}$ and (g) $5.8 \mu \mathrm{m}$

$\mathrm{TiO}_{2}$ film thicknesses are shown in Figure 7. It is evident that all the $\mathrm{TiO}_{2}$ films show good rectification behaviour. Also, it is clearly evident that all the $\mathrm{TiO}_{2}$ films have high shunt resistance and the shunt resistance is independent of $\mathrm{TiO}_{2}$ film thickness due to presence of an effective excitone blocking layer (Nazeeruddin et al., 2008) which in turn blocks the leakage current from the $\mathrm{TiO}_{2}$ surface to electrolyte. However, as $\mathrm{TiO}_{2}$ film thickness increases from $300 \mathrm{~nm}$ to $2.4 \mu \mathrm{m}$, a dramatic increase in series resistance is noticeable. As given in Table 2, the FF decreases as series resistance increases. Increase in series

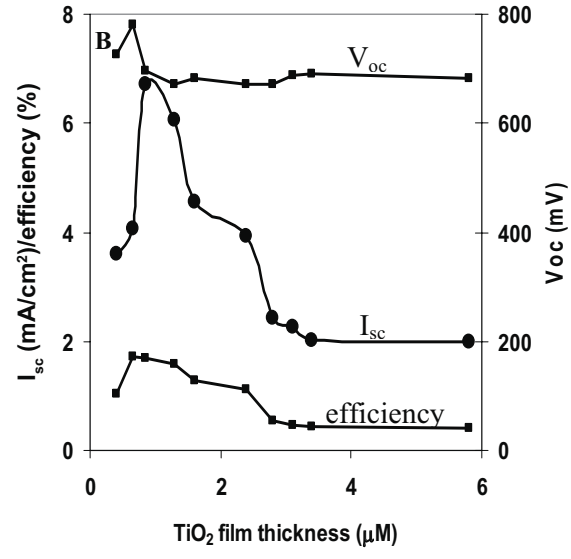

Figure 6(B): Dependence of short circuit current density $\left(\mathrm{mA} / \mathrm{cm}^{2}\right)$, open circuit potential $(\mathrm{mV})$ and efficiency (\%) against $\mathrm{TiO}_{2}$ film thickness

resistance with the increase of $\mathrm{TiO}_{2}$ film thickness leads to poor charge collection and hence observed decrease in efficiency as a function of $\mathrm{TiO}_{2}$ film thickness can be justified (Murayama \& Mori, 2006).

From these observations we can conclude that increasing the $\mathrm{TiO}_{2}$ thickness to an optimum value increases the $\mathrm{I}_{\mathrm{sc}}$ dramatically leading to higher efficiency compared to thinner cells $(300 \mathrm{~nm})$. Higher current for thicker cells is attributed to the higher dye adsorption on thicker $\mathrm{TiO}_{2}$ films. On the other hand, $\mathrm{FF}$ is higher for 


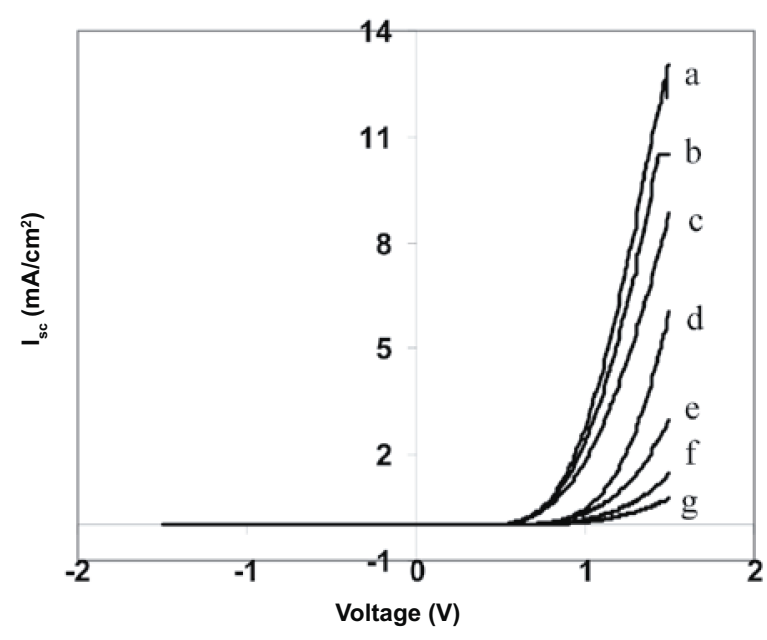

Figure 7: Rectification behaviour of SDSC prepared with D-A dye, Spiro-OMeTAD with the variation of $\mathrm{TiO}_{2}$ layer thickness (a) $350 \mathrm{~nm}$, (b) $650 \mathrm{~nm}$, (c) $850 \mathrm{~nm}$, (d) $1.3 \mu \mathrm{m}$, (e) $2.4 \mu \mathrm{m}$, (f) $3.1 \mu \mathrm{m}$ and (g) $5.8 \mu \mathrm{m}$

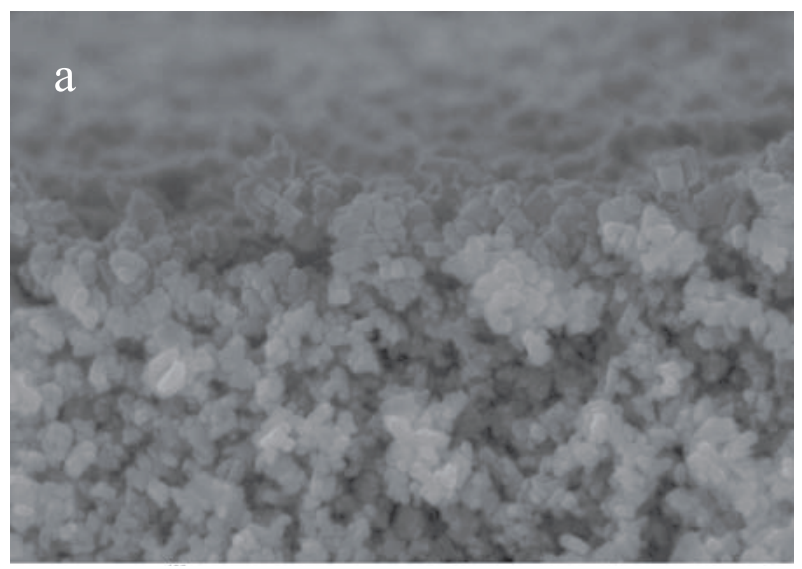

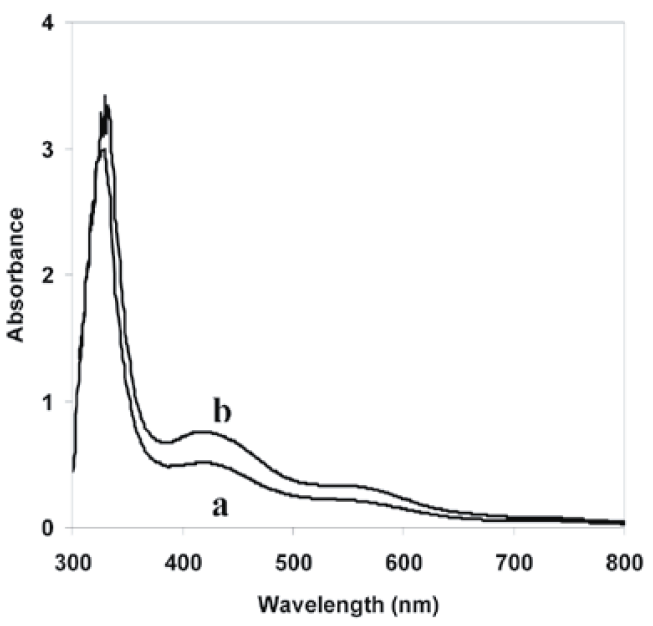

Figure 8: UV-Vis absorption spectra of Ru-TPA-NCS adsorbed $650 \mathrm{~nm}$ thick Dyesol- $\mathrm{TiO}_{2}$ film (sample B- 0.2:1, $\mathrm{TiO}_{2}:$ Terpinol wt/wt) (a) before $\mathrm{TiCl}_{4}$ treatment and (b) after $\mathrm{TiCl}_{4}$ treatment

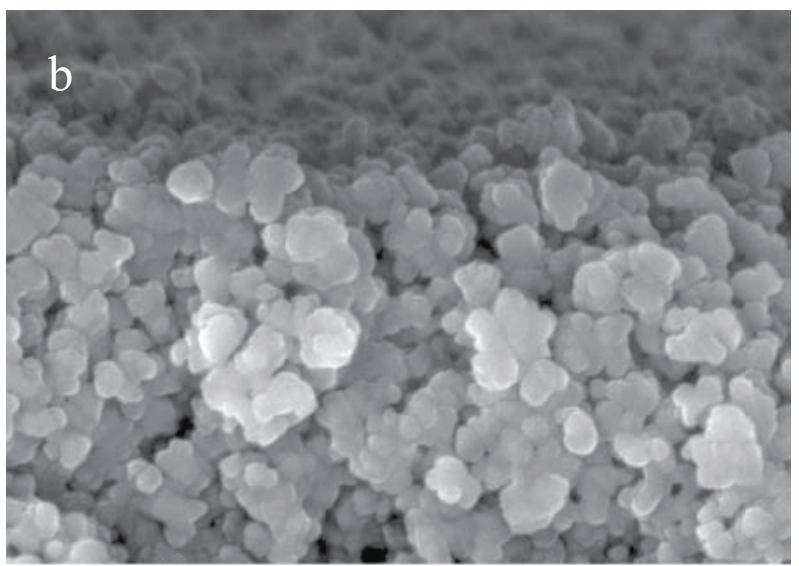

Figure 9: $\mathrm{SEM}$ images of $650 \mathrm{~nm}$ thick Dyesol- $\mathrm{TiO}_{2}$ film (sample B - 0.2:1, $\mathrm{TiO}_{2}$ : Terpinol wt/wt) (a) before $\mathrm{TiCl}_{4}$ treatment and (b) after $\mathrm{TiCl}_{4}$ treatment.

thinner cells due to lower series resistance. From this study it is clear that there should be a good balance between the $\mathrm{I}_{\mathrm{sc}}$ and $\mathrm{FF}$ in order to improve the performance of the SDSC. Furthermore, by cross-section SEM images analysis of hole conductor filled thin and thicker $\mathrm{TiO}_{2}$ films, it was also observed that the pore filling of the hole conductor in thinner $\mathrm{TiO}_{2}$ films is excellent compared to thicker $\mathrm{TiO}_{2}$ films. As a result of poor pore filling in thicker $\mathrm{TiO}_{2}$ films, higher recombination and in turn lower efficiency were expected compared to thinner $\mathrm{TiO}_{2}$ films.

It is well known that the $\mathrm{TiCl}_{4}$ treatment of the mesoporous $\mathrm{TiO}_{2}$ layer increases the overall solar cell performance of dye-sensitized solar cells (Sommeling et al., 2006; O'Regan et al., 2007). To optimize the solar cell performance further, the optimized solar cell was treated with $\mathrm{TiCl}_{4}$ and sintered at $450{ }^{\circ} \mathrm{C}$. As expected, for $\mathrm{TiCl}_{4}$ treated $\sim 650 \mathrm{~nm}$ thick $\mathrm{TiO}_{2}$ film, $\mathrm{I}_{\mathrm{sc}}$ and efficiency increased moderately. The observed $\mathrm{I}_{\mathrm{sc}}, \mathrm{V}_{\mathrm{oc}}, \mathrm{FF}$ and efficiency for $\mathrm{TiCl}_{4}$ treated $\sim 650 \mathrm{~nm}$ thick $\mathrm{TiO}_{2}$ film are $6.18 \mathrm{mAcm}^{-2}, 737 \mathrm{mV}, 0.44$ and $2.1 \%$ respectively. Compared to non-treated films, $25 \%$ increase in $\mathrm{I}_{\mathrm{sc}}$ was observed for the $\mathrm{TiCl}_{4}$ treated films while $\mathrm{V}_{\text {oc }}$ and $\mathrm{FF}$ decreased slightly for $\mathrm{TiCl}_{4}$ treated $\mathrm{TiO}_{2}$ films compared with the optimized SDSC device $\left(650 \mathrm{~nm}\right.$ thick $\mathrm{TiO}_{2}$ film). Comparison of dye-uptake (Figure 8) of both $\mathrm{TiCl}_{4}$ treated and non-treated $\mathrm{TiO}_{2}$ flms suggest that the 
increase in $\mathrm{I}_{\mathrm{sc}}$ was mainly due to enhanced dye adsorption as a result of increases in the effective surface area available for dye adsorption by increasing the roughness of the $\mathrm{TiO}_{2}$ particles. Further from SEM images shown in Figure $9 \mathrm{a}$ and $9 \mathrm{~b}$ for $\mathrm{TiCl}_{4}$ treated and non-treated $\mathrm{TiO}_{2}$ films respectively, the growth of $\mathrm{TiO}_{2}$ nanocrystallite size after $\mathrm{TiCl}_{4}$ treatment, resulting in enhanced interparticle $\mathrm{TiO}_{2}$ connection, is clearly evident. Hence, enhanced interparticle connections between $\mathrm{TiO}_{2}$ particles may result in enhanced charge collection by the anode through percolation of electrons and thereby increase in both $\mathrm{I}_{\mathrm{sc}}$ and efficiency (Sommeling et al., 2006; O'Regan et al., 2007).

For the best SDSC device reported to-date, an efficiency of $4 \%$ had been reported with Spiro-OMeTAD as hole conductor and the highest efficiency has been achieved with $\sim 2-2.5 \mu \mathrm{m}$ thick $\mathrm{TiO}_{2}$ film. Therefore, the $2.1 \%$ efficiency reported for a thin transparent $\mathrm{TiO}_{2}$ film $(650 \mathrm{~nm})$ in this investigation is remarkable compared to the film thickness of the best SDSC device reported, and could be assigned to high molar extinction coefficient of the D-A dye. The extended $\pi$-electron delocalization in the bpy ligand that results enables the D-A dye molecules to have very high molar extinction coefficients-more than twice that of commonly used N-719 dye (Karthikeyan et al., 2007). On the other hand, the D-A dye like Ru-TPA-NCS dye is known to minimize charge recombination processes occurring at $\mathrm{TiO}_{2} /$ dye and $\mathrm{TiO}_{2} /$ hexachloroethane (HC) interfaces by promoting spatial separation of charges due to the presence of electron donating triphenylamine group in the Ru-TPA-NCS. Therefore, it can be said that a high molar extinction coefficient of the donor antenna dye and extended spatial separation of electrons and holes play a significant role in enhancing the solar cell performance. It is known from previous work that the Ru-TPA-NCS dye provides improved performance in solid state solar cells, due partly to the improved wetting of the dye by the spiro-OMETAD hole transporting layer (Karthikeyan et al., 2007; Handa et al., 2007).

\section{CONCLUSION}

An efficient solid-state solar cell was fabricated using $650 \mathrm{~nm}$ thick and transparent mesoporous $\mathrm{TiO}_{2}$ electrodes sensitized with donor antenna dye Ru-TPA-NCS and Spiro-OMeTAD as hole conductor. $\mathrm{By} \mathrm{TiCl}_{4}$ treatment of the transparent $\mathrm{TiO}_{2}$ electrodes, $2.1 \%$ photoconversion efficiency was achieved. A high molar extinction coefficient of the donor antenna dye and extended spatial separation of electrons and holes in the Ru-TPA-NCS are reported to play a significant role in enhancing the solar cell performance due to the improved wetting of the dye by the spiro-OMeTAD hole transporting layer. Thicker transparent $\mathrm{TiO}_{2}$ electrodes with superior adsorption of Ru-TPA-NCS dye show poor solar cell efficiencies due to poor pore filling of spiro-OMeTAD hole conductor in $\mathrm{TiO}_{2}$ pores. If an efficient pore filling of hole conductor can be achieved in thicker $\mathrm{TiO}_{2}$ films, an even more efficient SDSC device can be fabricated.

\section{References}

1. Boschloo G., Marinado T., Nonomura K., Edvinsson T., Agrios A.G., Hagberg D.P., Sun L., Quintana M., Karthikeyan C.S., Thelakkat M. \& Hagfeldt A. (2008). A comparative study of a polyene-diphenylaniline dye and $\mathrm{Ru}(\mathrm{dcbpy})_{2}(\mathrm{NCS})_{2}$ in electrolyte-based and solid-state dye-sensitized solar cells. Thin Solid Films 516(20): 72147217.

2. Gratzel M. (2003). Dye-sensitized solar cells. Journal of Photochemistry and Photobiology C: Photochemistry Review 4 (2): 145-153.

3. Hagfeldt A. \& Grätzel M. (1995). Light-induced redox reactions in nanocrystalline systems. Chemical Review 95(1): 49-68.

4. Handa S., Wietasch H., Thelakkat M., Durrant J.R. \& Haque S.A. (2007). Reducing charge recombination losses in solid state dye sensitized solar cells: the use of donor-acceptor sensitizer dyes. Chemical Communications 17: $1725-1727$.

5. Karthikeyan C.S. \& Thelakkat M. (2008). Key aspects of individual layers in solid-state dye-sensitized solar cells and novel concepts to improve their performance. Inorganic Chimica Acta 361(3): 635-655.

6. Karthikeyan C.S., Peter K., Wietasch H. \& Thelakkat M. (2007). Highly efficient solid-state dye-sensitized $\mathrm{TiO}_{2}$ solar cells via control of retardation of recombination using novel donor-antenna dyes. Solar Energy Material and Solar Cells 91(5): 432-439.

7. Karthikeyan C.S., Wietasch H. \& Thelakkat M. (2007). Highly efficient solid-state dye-sensitized $\mathrm{TiO}_{2}$ solar cells using donor-antenna dyes capable of multistep charge-transfer cascades. Advanced Material 9(8): 1091-1095.

8. Kruger J., Plass R., Gratzel M., Cameron P.J. \& Peter L.M. (2003). Charge transport and back reaction in solidstate dye-sensitized solar cells; a study using intensitymodulated photovoltage and photocurrent spectroscopy. Journal of Physical Chemistry B 107(31): 7536-7539.

9. Murayama M. \& Mori T. (2006). Equivalent circuit analysis of dye-sensitized solar cell by using one-diode model: effect of carboxylic acid treatment of $\mathrm{TiO}_{2}$ electrode. Japanese Journal of Applied Physics 45(1B): 542-545.

10. O'Regan B.C., Durrant J.R., Sommeling P.M. \& Bakker N.J. (2007). Influence of the $\mathrm{TiCl}_{4}$ treatment on nanocrystalline $\mathrm{TiO}_{2}$ films in dye-sensitized solar cells. 2 . charge density, band edge shifts, and quantification of recombination losses at short circuit. Journal of Physical Chemistry C 111(37): 14001-14010. 
11. O'Regan B. \& Gratzel M. (1991). A low-cost, highefficiency solar cell based on dye-sensitized colloidal $\mathrm{TiO}_{2}$ films. Nature 353(6346): 737-740.

12. Peng B., Jungmann G., Jager C., Haarer D., Schmidt H.W. $\&$ Thelakkat M. (2004). Systematic investigation of the role of compact $\mathrm{TiO}_{2}$ layer in solid state dye-sensitized $\mathrm{TiO}_{2}$ solar cells. Coordination Chemical Review 248(13-14): 1479-1489.

13. Schmidet-Mende L. \& Gratzel M. (2006). $\mathrm{TiO}_{2}$ pore-filling and its effect on the efficiency of solid-state dye-sensitized solar cells. Thin Solid Films 500(1-2): 296-301.

14. Schmidet-Mende L., Zakuruddin S.M. \& Gratzel M. (2005). Efficiency improvement in solid-state-dye-sensitized photovoltaics with an amphiphilic Ruthenium-dye. Applied Physics Letters 86(1): 013504(1)-013501(3).

15. Snaith H.J., Karthikeyan C.S., Petrozza A., Teuscher J., Moser J.E., Nazeeruddin M.K., Thelakkat M. \& Grätzel M. (2008). High extinction coefficient "antenna" dye in solid-state dye-sensitized solar cells: a photophysical and electronic study. Journal of Physical Chemistry C 112(20): $7562-7566$.
16. Solbrand A., Lindström H., Rensmo H., Hagfeldt A., Lindquist S.E. \& Sodergren S. (1997). Electron transport in the nanostructured $\mathrm{TiO}_{2}$ electrolyte system studied with time-resolved photocurrents. Journal of Physical Chemistry B 101(14): 2514-2518.

17. Sommeling P.M., O'Regan B.C., Haswell R.R., Smit H.J.P., Bakker N.J., Smits J.J.T., Kroon J.M. \& vanRoosmalen J.A.M. (2006). Influence of a $\mathrm{TiCl}_{4}$ post-treatment on nanocrystalline $\mathrm{TiO}_{2}$ films in dye-sensitized solar cells. Journal of Physical Chemistry B 110(39): 19191-19197.

18. Thelakkat M., Schmitz C. \& Schmidt H.W. (2002). Fully vapor-deposited thin-layer titanium dioxide solar cells. Advanced Materials 14(8): 577-581.

19. Tennakone K., Bandara J., Bandaranayake K.M.P., Kumara G.R.A. \& Konno A. (2001). Enhanced efficiency of a dye-sensitized solar cell made from $\mathrm{MgO}$ coated nanocrystalline $\mathrm{SnO}_{2}$. Japanese Journal of Applied Physics 40(7B): L732-734.

20. van de Lagemaat J., Kopodakos N. \& Frank A.J. (2006). Effect of nonideal stastics on electron diffusion in sensitized nanocrystalline $\mathrm{TiO}_{2}$. Physical Review B 71(3): 1-7. 